\title{
A fogágybetegség mint az atheroscleroticus cardiovascularis betegség rizikófaktora
}

\author{
Gheorghita Dorottya dr. ${ }^{1}$ - Eördegh Gabriella dr. ${ }^{1}$ \\ Nagy Ferenc dr. ${ }^{2}$ - Antal Márk dr. ${ }^{1}$

\begin{abstract}
'Szegedi Tudományegyetem, Fogorvostudományi Kar, Konzerváló és Esztétikai Fogászati Tanszék, Szeged Invazív Kardiológiai Részleg, Szeged
\end{abstract} \\ ${ }^{2}$ Szegedi Tudományegyetem, Általános Orvostudományi Kar, II. Belgyógyászati Klinika és Kardiológiai Központ,
}

A cardiovascularis betegség világszerte a halálozás és a rokkantság vezető oka. Ezen halálozások többségének hátterében atheroscleroticus és thromboembolisatiós folyamatok állnak, amelyek ischaemiás szívbetegség és stroke kialakulásához vezetnek. A gyulladásos folyamatok szerepe jól dokumentált mind az atherosclerosis, mind az atherothrombosis kialakulásában. Egyre több tudományos eredmény támasztja alá a fogágybetegség, azon belül is a parodontitis szerepét az atherosclerosis és így a cardiovascularis betegségek egyik potenciális rizikófaktoraként. A krónikus gyulladásban lévő, fertőzött parodontalis tasakban lévő kórokozók, valamint azok toxinjai és bomlástermékei növelik a szervezetben zajló szisztémás gyulladásos választ. A szisztémás keringésbe jutva és magukat az atheroscleroticus plakkokat is infiltrálva, további lokális és szisztémás gyulladásos választ indukálnak, összességében fokozzák az atherosclerosis progresszióját, és potenciálisan növelik a cardiovascularis megbetegedések kialakulásának kockázatát. Ennek megfelelően a jó általános szájhigiénia, súlyosabb esetekben parodontalis terápiával elősegítve, potenciálisan csökkentheti a cardiovascularis megbetegedések kialakulásának kockázatát, és része lehet a primer és szekunder prevenciós tevékenységeknek is. Jelen közleményünk célja a fogágybetegség és a cardiovascularis megbetegedések közötti lehetséges patofiziológiai kapcsolatok összefoglalása epidemiológiai vizsgálatok alapján, klinikai evidenciák bemutatása a fogágybetegség és bizonyos cardiovascularis kórképek között, valamint megvizsgálni a parodontalis terápia lehetséges hatásainak szerepét a cardiovascularis megbetegedések megelőzésében, kezelésében.

Orv Hetil. 2019; 160(11): 419-425.

Kulcsszavak: odontogén góc, parodontitis, cardiovascularis megbetegedések, bacteriaemia

\section{Periodontal disease, a risk factor for atherosclerotic cardiovascular disease}

Cardiovascular disease is recognized as the leading cause of death and disability in the world. The majority of these deaths can be attributed to atherosclerotic disease and thromboembolic events leading to ischemic heart disease and stroke. The role of inflammation is well recognized in the pathogenesis of atherosclerosis and atherothrombosis. Increasing number of studies support the hypothesis that periodontal disease, specifically periodontitis, is a potential risk factor for atherosclerosis and thus cardiovascular disease. Chronic infections of periodontal pockets act as reservoirs for pathogenic microorganisms, their toxins and degradation products, raising the overall systemic inflammatory burden. Entering the circulation and atherosclerotic lesions themselves, they lead to further local and systemic inflammatory response, in all contributing to atherosclerosis progression, potentially increasing cardiovascular risk. Along these lines, good oral health in general and the periodontal treatment in more severe cases may play a role in cardiovascular risk reduction, primary and secondary prevention. The present review summarizes the possible pathophysiological mechanisms linking periodontal and cardiovascular pathology, lists clinical evidence between periodontitis and specific forms of cardiovascular disease and looks forward at the potential role of periodontal treatment in cardiovascular disease prevention and treatment.

Keywords: odontogenic foci, periodontitis, cardiovascular disease, bacteraemia

Gheorghita D, Eördegh G, Nagy F, Antal M. [Periodontal disease, a risk factor for atherosclerotic cardiovascular disease]. Orv Hetil. 2019; 160(11): 419-425.

(Beérkezett: 2018. szeptember 9.; elfogadva: 2018. október 27.) 


\section{Rövidítések}

ADMA = aszimmetrikus dimetil-arginin; $\mathrm{CPI}=($ community periodontal index) Parodontalis kezelés szükségességét vizsgáló index; $\mathrm{CRP}=\mathrm{C}$-reaktív protein $; \mathrm{HDL}=($ high-density lipoprotein) magas sürúségú lipoprotein; Hgmm = higanymilliméter; ICAMI = intercelluláris adhéziós molekula; IL6 = interleukin-6; LDL = (low-density lipoprotein $)$ alacsony sűrüségü lipoprotein; LPS = lipopoliszacharid; NF- $\kappa \mathrm{B}=$ nukleárisfaktor-kappa-B; PAIl = plazminogénaktivátorinhibitor- $1 ; \mathrm{PCR}$ = polimeráz-láncreakció; PDSI = (periodontal severity index $)$ Parodontalis pusztulás mértékét vizsgáló index; Thl $=$ T-helper- $1 ;$ TLR $=$ (Toll-like receptor $)$ Toll-szerü receptor; TNF $\alpha=$ tumornekrózisfaktor-alfa; VCAMl = vascularis sejtadhéziós molekula; $\mathrm{WHO}=($ World Health Organization $)$ Egészségügyi Világszervezet

Napjainkban egyre nagyobb figyelmet kapnak a szájüregi gyulladásos állapotok, melyeknek gócként fontos szerepük lehet a távoli szervekben másodlagosan kialakuló megbetegedések létrejöttében. Odontogén gócként említhető meg például a foggyökércsúcs körüli gyulladás, a postextractiós gyulladás, az át nem tört fertőzött fog, valamint a fertőzött parodontalis tasak és annak krónikus következménye, a parodontitis [1,2]. A szájüregi infekcióból kiinduló távoli gyulladás többféle módon, a kórokozóknak, illetve azok toxinjainak és bomlástermékeinek terjedése, valamint speciális immunfolyamatok beindítása révén is létrejöhet [1], és kapcsolatba hozható például a krónikus plakkpsoriasissal [3], a rheumatoid arthritisszel [4], a diabetes mellitusszal, bizonyos tüdőbetegségekkel, a koraszüléssel és a kis születési súllyal [5], valamint a szív- és érrendszeri megbetegedésekkel is. Közleményünkben részletesen az utóbbi témakörrel foglalkozunk, irodalmi áttekintés formájában.

\section{A parodontitis}

A parodontitis olyan destruktív gyulladásos megbetegedés, amely hat a fogak támasztószöveteire: károsítja az ínyt, a parodontalis rostokat, a cementszövetet, illetve az alveoluscsontot is. A legtöbbször kevert bakteriális (Gram-negatív és Gram-pozitív baktériumok által létrehozott) fertőzés talaján alakul ki, melynek jellemző forrása a dentális plakk, azaz a fogak felszínén kialakuló szervült biofilmréteg.

Különös figyelmet igényel, hogy egyes parodontalisplakk-baktériumok (valamint azok endo- és exotoxinjai) roncsolva a fogágy szöveteit és áttörve az erek fala által alkotott barriert, a véráramlásba jutva akár periodikus, rekurrens, tranziens bacteriaemiát is létrehozhatnak [6].

Egy 2011-es közlemény szerint a középsúlyos (CPI 3.) és súlyos (CPI 4.) fogágybetegség a hazai felnőtt lakosságnak körülbelül a 30\%-át érinti [7]. A középsúlyos és súlyos formák esetében a maximális parodontalistasakmélység a $4 \mathrm{~mm}$-t is meghaladja. Az ínygyulladás foka, valamint a parodontalis tasak mélysége pedig hatással van a kialakuló bacteriaemia mértékére is [5]. Fogászati kezelések, invazív beavatkozások, de bizonyos esetekben akár az egyszerú rágás vagy fogmosás is elôsegítheti a szájüregi mikroorganizmusok véráramba kerülését, fóleg azon betegeknél, akiknél ínygyulladás és/vagy parodontitis áll fenn. A parodontalis gyulladásban igen gyakran kimutatható Porphyromonas gingivalis baktérium például képes az érfal direkt inváziójára: virulenciafaktorainak (például az endotoxinja, a külső membránvesiculái, a fimbriái, a hemagglutininjai vagy az úgynevezett gingipain enzimje) segítségével endothelsejt-irritációt és ennek következtében azonnali gyulladásosválasz-reakciót indukál. Egy másik jellegzetes parodontopathogen, az Aggregatibacter actinomycetemcomitans szabad szolúbilis bakteriális komponensei hasonló folyamatokat indíthatnak be $[8,9]$. A kórokozók többféle módon is hathatnak az érfal gyulladásos folyamataira és az atheroscleroticus plakk progresszivitására: akár az érfal direkt kontaminációjával, endotoxinfelszabadulás útján lokálisan és szisztémásan, autoimmun reakció beindításával a Hsp60-hősokkfehérje mikrobiális homológján keresztül, valamint nagyfokú gyulladásos citokin felszabadulásának indukálásával, amely pedig a lipoproteinek metabolizmusát befolyásolja (1.ábra) [9].

\section{A parodontitis és a cardiovascularis megbetegedések közötti kapcsolatot feltáró epidemiológiai vizsgálatok}

A cardiovascularis megbetegedések világszerte az egyik leggyakoribb mortalitással járó megbetegedéseknek számítanak. Egy 2015-ös, a WHO által készített felmérés alapján a világon 17,7 millió ember halálát okozta valamilyen cardiovascularis betegség, ezek közül is jelentősen kiemelkednek a szívkoszorúér-betegség okozta halálesetek 7,4 milliós számmal, illetve a stroke miatt bekövetkezett halálesetek 6,4 milliós számmal [10].

Számos epidemiológiai vizsgálat mutat rá a súlyos fokú fogágybetegség és az atherosclerosis közötti kapcsolatra. A jelenlegi álláspont szerint azonban a parodontitis és a cardiovascularis megbetegedések között direkt ok-okozati összefüggés egyértelmúen nem mutatható ki, ugyanakkor számos közös rizikótényezôn osztoznak (például dohányzás, elhízás és a 2-es típusú diabetes mellitus), ami felveti annak lehetőségét, hogy a két állapot között bizonyos patofiziológiai kapcsolat állhat fent. Az egyik legkorábbi, igen nagy figyelmet keltô esetkontroll publikáció a lehetséges összefüggésről 1989ből, Mattilától és munkatársaitól származik, melyben leírták, hogy a vizsgált, myocardialis infarctuson átesett személyek szájüregi állapota (cariesek, periodontitis, periapicalis elváltozások, pericoronitis jelenléte) szignifikánsan rosszabb volt, összehasonlítva azt a kontrollcsoportéval [11]. Ezt követően, 1993-ban is megjelent Mattila és mtsai nevéhez füződően egy szignifikáns pozitív kapcsolatot leíró közlemény, a vizsgált személyek co- 
ronariaszúkületének mértéke és szájüregi állapota között [12]. 2000-ben közölt vizsgálatában Emingil is összefüggést talált: az akut myocardialis infarctuson átesett személyeknél szignifikánsan magasabb arányban volt jelen a szondázási ínyvérzés, valamint a $\geq 4 \mathrm{~mm}$-es tasakmélység, összehasonlítva azt a krónikus koszorúér-betegségben szenvedőknél mérttel [13]. Geerts 2004-es eset-kontroll vizsgálatában szintén pozitív eredményt kapott: a koszorúér-megbetegedésben szenvedők között szignifikánsan magasabb arányban fordult elő parodontitis, mint az egészséges kontrollcsoportban [14].

Igen nagy számban jelentek meg a témával kapcsolatos keresztmetszeti vizsgálatok is, melyek közül kiemelendő Beck és mtsai 2001-ben közölt munkája, amelyben megállapították, hogy a parodontitis hatással lehet az atheromaformációra [15]. Shimazaki 2004-es közleményében leírja, hogy a tasakmélység, a tapadásveszteség, a plakkindex és a fogak száma szignifikáns összefüggésben van a bal kamrai hypertrophiával, amely állapot a hosszan tartóan fennálló magas vérnyomás klinikai manifesztációjának tekinthető [16]. Holmlund és mtsai 2006os közleményükben prezentálták a súlyos parodontalis megbetegedés (PDSI>2,9) és a magas vérnyomás, valamint a myocardialis infarctus közötti szignifikáns összefüggést [17]. Desvarieux és mtsai egy 653 beteget magában foglaló vizsgálatban találtak kapcsolatot a subgingivalis bakteriális fertőzöttség mértéke, a szisztolés és a diasztolés vérnyomás, valamint a magasvérnyomás-betegség előfordulása között [18].

A kérdéskört felölelő longitudinális vizsgálatok még nagyobb bizonyító erővel rendelkeznek, azonban ezen vizsgálatok többnyire retrospektívek. Pozitív összefüggést írt le például az az 1993-ban publikált közlemény, amelyben a nyomon követett személyeket 14 éves intervallumon keresztül vizsgálva kimutatható volt, hogy a kezdeti parodontitis fokozta a coronariamegbetegedések kockázatát [19].

Mendez és mtsai 1998-as megjelenésű, több mint 25 évet felölelő utánkövetéses vizsgálatuk eredményéből azt a következtetést vonták le, hogy a parodontitis független kockázati tényező a perifériás érbetegség kialakulásában [20].

Nem találtak azonban szignifikáns kapcsolatot Hujoel és mtsai utánkövetéses vizsgálatukban a coronariamegbetegedés és a gingivitis, valamint a parodontitis között [21].

Lafon és mtsai 2014-es, kohorszvizsgálatok alapján készített metaanalízisközleményükben viszont megállapították, hogy a stroke kialakulásának kockázata szignifikánsan magasabb parodontitis jelenlétében [22].

Az elmúlt évek egyik igen meghatározó közleménye a témában a PAROKRANK-vizsgálat, mely Rydén és mtsai nevéhez füződik. Ezen prospektív, eset-kontroll vizsgálatban első myocardialis infarctuson átesett betegeknél, valamint egészséges kontrollcsoportnál vizsgálták a parodontalis statust, a panorámaröntgen alapján megítélt fogágycsontveszteség mértékét. Az első myocardialis in- farctus rizikója a rizikófaktorokra történő illesztést követően is szignifikánsan magasabb volt a parodontitisben szenvedő betegeknél, igazolva a parodontitist mint független rizikófaktort az akut cardiovascularis események kialakulásában [23].

Kiemelendő emellett még Beukers és mtsai vizsgálata is, amelyben mintegy 15 éves intervallumban, több mint 60 000, fogászati gondozás alatt álló betegnél hasonlították össze retrospektív módon a beteg parodontalis statusát és cardiovascularis megbetegedéseit, valamint általános rizikófaktorait. Korra, nemre és ismert rizikófaktorokra történő korrekció után a parodontitis független rizikófaktornak bizonyult mind az akut myocardialis infarctus, mind az akut cerebrovascularis események esetében [24].

Összefoglalva tehát elmondható, hogy az utóbbi évek közleményeinek nagy része pozitív összefüggést írt le a parodontitis és a cardiovascularis események között, azonban további vizsgálatok szükségesek a pontos patofiziológiai mechanizmusok tisztázása érdekében [2527].

\section{$\mathrm{Az}$ atherosclerosis patomechanizmusa - potenciális kapcsolódási pontok a parodontitisszel}

$\mathrm{Az}$ atherosclerosis olyan kórkép, melynél a közepes és nagy artériák falában progresszív atheromás plakk képződik. Kialakulása a ma elfogadott elmélet szerint a kezdeti endothelsérülésen, a kialakult endotheldiszfunkción és az azt követő gyulladásos válaszon alapul. Az endothelialis diszfunkció az atherosclerosis patogenezisének kezdőpontja, a cardiovascularis megbetegedések kialakulásának egyik alappillére. A gyulladásos folyamatok következtében az érfal permeabilitása megnő, és különböző plazmaösszetevők (elsősorban lipoproteinek, például az LDL) kerülnek a subintimalis térbe (az extracelluláris mátrixba, illetve a simaizomsejtek proteoglikánjaihoz kötődve). Az LDL-partikulák így csapdába esnek, majd lerakódásuk után fokozott oxidálódásuk indul meg. Ezzel egy időben a károsodott endothelialis sejtek megkezdik a különböző felületaktív adhéziós molekuláik termelését (mint például az ICAMl-et, a VCAMl-et és a P-szelektint), amelyek az immunsejtek kitapadásáért, migrációjáért és kumulálódásáért is felelősek. A gyulladásos válaszban a makrofágok elsősorban az oxidált LDL-t távolítják el: bekebelezik őket LDL- és scavenger receptoraik segítségével. Ez az egyik fö oka a habossejt-képződésnek, ezáltal pedig az atheromás plakk kialakulásának [28].

$\mathrm{Az}$ atheroscleroticus folyamat lassú progressziója idővel az artéria súlyos beszúküuléséhez, a célszerv krónikus keringési elégtelenségéhez vezethet, például a krónikus ischaemiás szívbetegség esetén. Ugyanakkor az atheromás plakk rupturája következményes thrombocytaaktivációval és thrombusformálódással a célszerv akut ischae- 
miás állapotát váltja ki, például akut myocardialis infarctus, stroke vagy akut kritikus végtagischaemia esetén [28].

A krónikus parodontalis gyulladás indukálta szisztémás gyulladásos válasz, továbbá maguk a parodontopathogen mikroorganizmusok több támadásponton keresztül is hozzájárulhatnak a fent részletezett atheroscleroticus folyamat progressziójához. A bakteriális lipopoliszacharid (endotoxin) növelheti a makrofágok koleszterineliminációját, ezáltal pedig hozzájárul a habossejt-képződéshez, egyúttal az atheroscleroticus plakk képződéséhez is [28]. A bakteriális inváziót követő azonnali gyulladásosválasz-reakcióban felszabaduló proinflammatoricus citokinek simaizom-proliferációt iniciálhatnak. Ez a vasomotorfunkcióra is hatással lehet, illetve a proliferáció következtében létrejövő fibrosis az atheroscleroticus plakk progresszióját befolyásolhatja [8].

A bakteriális lipopoliszacharidok, valamint a hősokkfehérjék keresztreaktív autoantitestek és T-sejtek képződését is indukálhatják, melyek az endothelsejteket károsítva szintén az atherosclerosis kialakulását és progresszióját segítik elő. Erre a folyamatra példa lehet a Porphyromonas gingivalis "GroEL” nevü chaperonja (dajkafehérjéje), amely hasonló szerkezetü, mint a humán endothel Hsp60-hősokkfehérjéje [9].

A krónikus bacteriaemia következtében termelődött antitestek keresztreakciót indíthatnak be az endothelsejtek és a módosult LDL között, ezáltal fokozzák az érfalon keresztül a lipidek sejtekbe való bejutását. Ezek az antitestek és gyulladásos citokinek elősegítik a Thl-választ, ezáltal további makrofágokat aktiválnak az atheromában, és fokozzák az atherogenesist [8].
A Toll-szerű receptorok családjának közös jellemzője a kórokozók elleni immunválasz megindítása. Expressziójuk kimutatható az antigénprezentáló sejteken, valamint más immunsejteken (például a hízósejteken, valamint a T- és B-sejteken), illetve egyéb sejteken is (például az endothel-, epithel- és simaizomsejteken). A különböző TLR-ok ligandumspecificitása eltérő, itt azonban mindenképpen említést kell tenni a TLR2- és a TLR4-receptorról. A TLR2-receptor ligandjai közé tartoznak a lipoproteinek és a Porphyromonas gingivalis LPS-ja, míg a TLR4-receptor ligandjai közé az egyéb Gram-negatív baktériumok lipopoliszacharidjai - mint idegen eredetü molekulák -, valamint a Hsp60-hősokkfehérje és az oxidált LDL - mint a szervezet saját, veszélyt jelentő molekulái - sorolhatók. A ligandumot kötött receptorok azonnali gyulladásos mediátor képzésére késztetik a sejteket a NF- $\kappa \mathrm{B}$ transzkripciós faktor múködésén keresztül, az így kialakuló gyulladás pedig hatással lehet az atherosclerosis kialakulására is (1. ábra) [29].

\section{Humán atheromás plakk - bakterológiai vizsgálatok}

Az elmúlt nagyjából húsz évet felölelő időszakban számos publikáció igazolta atheromás plakkokban parodontopathogen baktériumok jelenlétét. Chin például 1999-ben megjelent közleményében írja le, hogy immunhisztokémiai módszerrel sikerült kimutatnia a Porphyromonas gingivalis és a Streptococcus sanguis baktériumot humán atheromás plakkból [30]. Haraszthy és mtsai PCR segítségével Actinobacillus actinomycetemcomi-

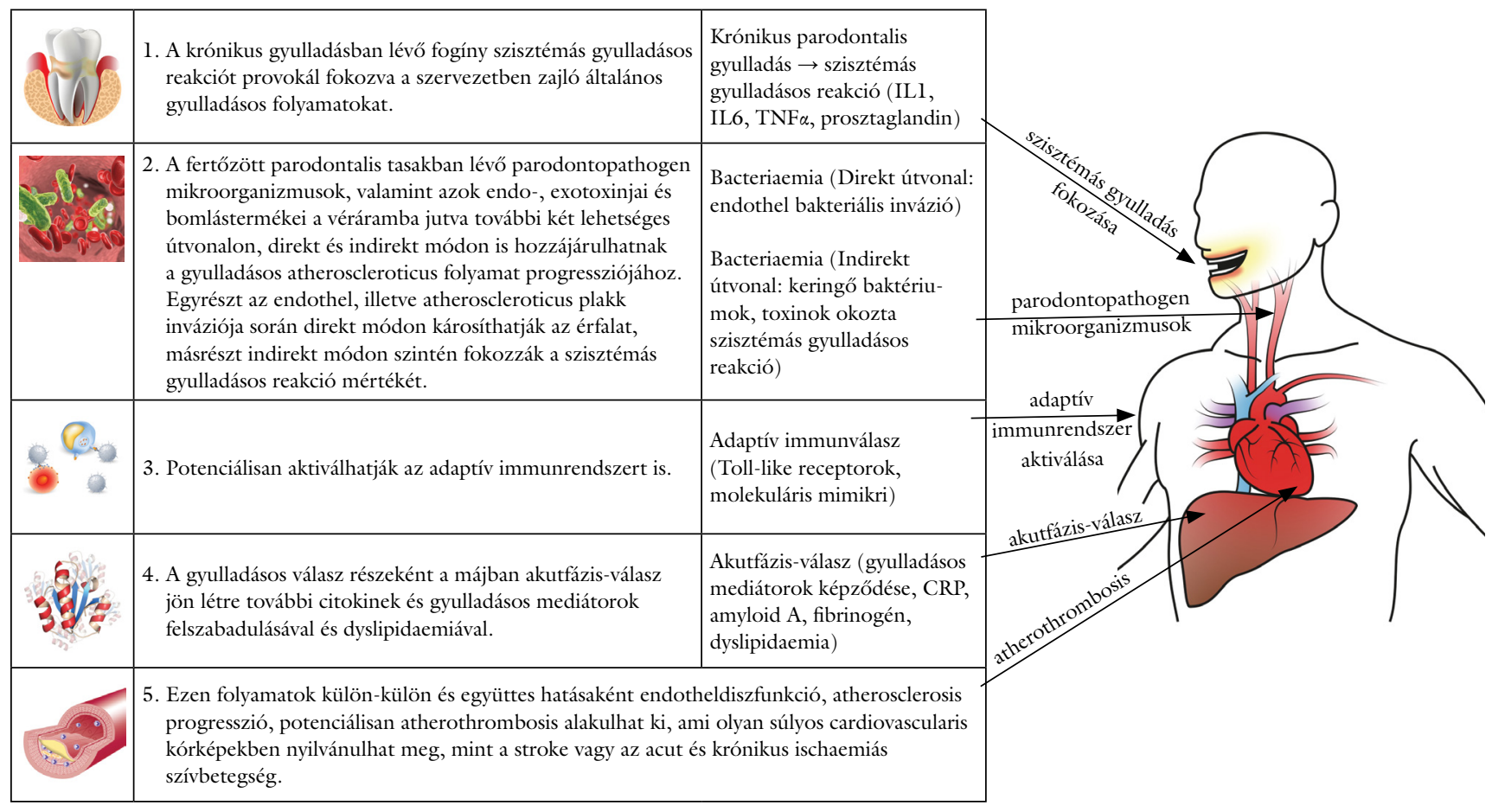

1. ábra $\quad$ A parodontitis és a cardiovascularis megbetegedés közötti patofiziológiai kapcsolat lehetséges útvonalai 
tans-, Tannerella forsythia-, Porphyromonas gingivalis- és Prevotella intermedia-törzseket, illetve azok antigénjeit izolálták [31]. Zaremba 2006-os megjelenésü vizsgálata nagy számban mutatott ki Porphyromonas gingivalist és Treponema denticolát atheromás plakkban [32].

\section{A parodontitis és a cardiovascularis betegségek indirekt markereinek összefüggései}

\section{Gyulladásos mediátorok, szisztémás gyulladásos válasz}

A parodontitis kapcsolatba hozható bizonyos gyulladásos biomarkerek szérumszint-emelkedésével is. A megemelkedett IL6-szint például a hepatocytákat CRP, valamint egyéb akutfázis-fehérjék és prokoaguláns mediátorok (PAIl, fibrinogén) szintézisére stimulálja, melyek kimutathatók parodontitises betegekben (1. ábra) [33]. Ezt támasztja alá Schwahn és Bizzarro vizsgálata is, melyben azt találták, hogy parodontológiai betegek szérumPAIl - és fibrinogénszintje magasabb volt az egészséges kontrollokhoz képest [34, 35].

A TNF $\alpha$ proinflammatoricus citokin fontos prediktora lehet a cardiovascularis eseményeknek, és Passoja vizsgálatában például magasabb TNF $\alpha$-szérumszint volt mérhető azon betegeknél, akiknél egyúttal fogágybetegség is fennállt $[36,37]$.

A CRP akutfázis-fehérje egyébiránt a szisztémás gyulladás és az endothelfunkció klinikai vizsgálatának egyik markere [8], és hozzájárulhat a magas vérnyomás kialakulásához az endothelsejtek nitrogén-monoxid-produkciójának csökkentésével, ami pedig így vasoconstrictióhoz és fokozott endothelin-1-képződéshez vezet. Emellett proatherogen faktorként is múködhet, az angiotenzin-1-receptor-expresszió szabályozásán keresztül. Az emelkedett CRP-szint (több, mint 2,1 mg/l) kapcsolatba hozható a fokozott incidenciájú akut thromboticus eseményekkel, mint például a stroke-kal és a myocardialis infarctussal [38]. Korábbi kutatások megállapították azonban, hogy az akutfázis-fehérjék szérumszintje nem csak akut és súlyos gyulladásos megbetegedésekben emelkedhet meg: hosszan tartó, krónikus gyulladások is befolyással lehetnek a szérumszintjükre. A szintemelkedés valószínűsíthetően dózisfüggő: az adott betegség súlyossági fokától függően változhat. Több vizsgálat eredménye is bizonyos fokú CRP-szérumszint-emelkedést mutatott ki krónikus parodontitis esetében, az agresszív, gyorsan progrediáló formánál pedig szignifikáns, nagyfokú CRP-szint-emelkedés volt kimutatható [33]. A krónikus parodontitisben szenvedő betegek szérumCRP-szintje akár hosszan tartóan emelkedett lehet, ez pedig súlyosbíthatja a már folyamatban lévő gyulladásos folyamatokat az atheroscleroticus laesiókban, így fokozva a cardio- és cerebrovascularis események kialakulásának kockázatát [39].

\section{Szérumlipidszint}

A cardiovascularis megbetegedések egyik további, igen jelentős rizikótényezője a magas vérzsírszint. Nepomuceno metaanalízisközleményében, több publikációt áttekintve vizsgálta meg a szérumlipidszint összefüggéseit a parodontalis megbetegedéshez viszonyítva, és megállapította, hogy krónikus parodontitises betegeknél szignifikánsan emelkedett a szérum-LDL- és -triglicerid-szint, és szignifikánsan alacsonyabb a szérum-HDL-szint. Emelkedett volt a szérumtotálkoleszterin-szint is, azonban nem volt szignifikáns a különbség, összehasonlítva az eredményt az egészségesekével [40].

\section{Endotheldiszfunkció}

Egy eset-kontroll tanulmányban az arteria brachialis endotheldependens, áramlásfüggő dilatatióját mérték egészséges és parodontitisben szenvedő betegeknél. Az endothelfunkció monitorozásának ez az egyik lehetséges és igen gyakran alkalmazott módja. A vizsgálat során, a dilatatio százalékos és mm-ben kifejezett értéke is szignifikánsan alacsonyabb volt az egyébként egészséges, csak súlyos parodontitisben szenvedő betegeknél, összehasonlítva azt a kontrollcsoportéval [41]. Higashi egy 2008-as felmérésében a normo- és hipertenzív betegeknél a már eleve meglévő gyenge endotheliumdependens vasodilatatio szintén rosszabb volt, ha egyúttal enyhe vagy középsúlyos fogágybetegség állt fenn. A parodontitisben szenvedő betegeknél ugyanakkor gyulladásos markerek (CRP és IL6) szignifikánsan magasabb szérumszintje is mérhető volt [42]. Az endothelsejtek által termelt nitrogén-monoxid képződését gátolja és ezáltal az endotheldiszfunkcióhoz is hozzájárul az úgynevezett aszimmetrikus dimetil-arginin (ADMA), melynek szintje kimutathatóan magas volt a magas vérnyomásban szenvedő parodontológiai betegekben [43]. Ez további bizonyítéknak tekinthető a parodontitis és az endotheldiszfunkció kapcsolatára.

\section{A parodontalis terápia hatása a gyulladásos markerekre, potenciális szerepe a cardiovascularis betegségek primer és szekunder prevenciójában - humán intervenciós vizsgálatok}

A parodontitis és a cardiovascularis betegségek lehetséges kapcsolata szempontjából érdekes lehet az a kérdés, hogy változik-e a cardiovascularis állapot a parodontitis javulásának hatására. Ennek közvetett bizonyítéka például Vidal és mtsai vizsgálata, melyben a parodontalis terápia szignifikánsan csökkentette a szérumfibrinogén-, -CRP- és -IL6-szintet, gyógyszerre nem reagáló magas vérnyomásos betegeknél [44.] Freitas több publikáció eredményeit összefoglalva írja le, hogy nem sebészi parodontalis terápia hatására szignifikáns CRP-szint-csökke- 
nés érhetô el [45]. D’Aiuto 2013-as metaanalízisközleményében bemutatta, hogy a parodontalis terápia után progresszív javulás volt megfigyelhető a lipidmarkerek, a CRP, az IL6, a fibrinogén és a szolúbilis E-szelektin szérumszintjében [46]. A TNF $\alpha$-szérumszint változtatását célzó vizsgálatok eredményei esetében azonban ellentmondásosak az irodalmi adatok. Jelenleg nagyjából azonos számú publikáció írja le a parodontalis terápia pozitív, valamint semleges hatását is a $\mathrm{TNF} \alpha$-szérumszint változására. A parodontalis terápia $\mathrm{TNF} \alpha$-szintet befolyásoló hatásának tisztázására ezért további vizsgálatok szükségesek a szakirodalomban [46]. További vizsgálatok szükségességére hívja fel a figyelmet egy áttekintő közlemény is, amely több intervenciós (nem sebészi) parodontalis beavatkozás vizsgálatait gyújtötte egybe, és leírta, hogy közvetlenül a kezelések után szignifikáns emelkedés mutatkozott a TNF $\alpha$, a CRP és az IL6 szérumszintjében. Ez alátámasztja a parodontalis terápia következtében kialakuló bacteriaemia lehetőségét is [47]. A fenti eredmények alapján különbség mutatkozik a parodontalis terápiák rövid és hosszú távú hatásában a szisztémás gyulladási faktorok szintjére, ezért az eddigi és a jövőbeli kutatások eredményeinek értelmezése során érdemes ezt a két tényezőt egymástól elkülönítve figyelembe venni.

Míg a parodontalis kezelésnek a keringő gyulladásos markerekre kiváltott csökkentő hatását egyre több vizsgálat támasztja alá, addig hatásossága a cardiovascularis rizikó csökkentésében, a primer és szekunder események megelőzésében már jóval vitatottabb. Tonetti és mtsai megfigyelése szerint intenzív parodontalis terápia hatására javulás volt megfigyelhető a kezelés után hat hónappal az endotheldependens vasodilatatio értékeiben normoés hipertenzív betegeknél [48]. Ezzel ellentétben Saffiés $m$ tsai randomizált, kontrollált, prospektív vizsgálatban (stabil angina pectorisban szenvedő betegeknél), amelynél parodontalis terápiában részesítették a betegeket, nem találtak szignifikáns különbséget az endotheldependens vasodilatatio mértékében a kontrollcsoporthoz viszonyítva [49]. Li és mtsai 2017-ben megjelent metaanalízisükben felhívják a figyelmet az ennek a kérdésnek az egyértelmú eldöntésére alkalmas randomizált, kontrollált, prospektív és klinikai végpontokra koncentráló vizsgálatok jelenlegi hiányára és jövőbeli szükségességére [50].

\section{Következtetés}

Közleményünkben epidemiológiai és klinikai vizsgálatok tükrében megkíséreltük bemutatni a parodontalis megbetegedések, kiemelten a parodontitis és az atherosclerosis talaján kialakult cardiovascularis betegségek közötti lehetséges kapcsolatot. A kérdéshez kapcsolódó szakirodalom áttekintése során összefüggést találtunk a parodontalis betegség megléte, annak súlyossága és olyan jelentős cardiovascularis kórképek, mint például a magas vérnyomás, a myocardialis infarctus, a stroke és a perifé- riás érbetegség között. Számos vizsgálat nemcsak rávilágított a parodontitis és bizonyos cardiovascularis betegségek együtt járására, hanem igazolta a parodontitis aktív kezelésének pozitív hatását a szisztémás gyulladásos reakció csökkentésében, felvetve ennek szerepét cardiovascularis megbetegedések primer és szekunder prevenciójában. További kutatás szükséges azonban a pontos közös patofiziológiai mechanizmusok megértéséhez, illetve a parodontalis kezelés potenciális szerepének megítélésére a cardiovascularis rizikó csökkentésében.

Anyagi támogatás: A közlemény megírása anyagi támogatásban nem részesült.

Szerzői munkamegosztás: A kézirat megszövegezésében mindegyik szerző részt vett. G. D. az irodalmi áttekintésben, N. F. a kardiológiai vonatkozások kialakításában, A. M. a koncepció kidolgozásában, E. G. a végleges forma kialakításában vállalt meghatározó szerepet. A cikk végleges változatát valamennyi szerző elolvasta és jóváhagyta.

Érdekeltségek: A szerzőknek nincsenek érdekeltségeik.

\section{Irodalom}

[1] Gorzó I. Dental focal infection. Literature review. [A fogeredetü góc. Irodalmi áttekintés.] Fogorv Szle. 2003; 96: 3-8. [Hungarian]

[2] Párkányi L, Vályi P, Nagy K, et al. Odontogenic foci and systemic diseases. [Az odontogén góc és a szisztémás betegségek.] Orv Hetil. 2018; 159: 415-422. [Hungarian]

[3] Gheorghita D, Antal MÁ, Nagy K, et al. Smoking and psoriasis as synergistic risk factors in periodontal disease. [Dohányzás és pikkelysömör mint együttes rizikófaktor a fogágybetegségben.] Fogorv Szle. 2016; 109: 119-124. [Hungarian]

[4] Antal M, Battancs E, Bocskai M, et al. An observation on the severity of periodontal disease in past cigarette smokers suffering from rheumatoid arthritis - evidence for a long-term effect of cigarette smoke exposure? BMC Oral Health 2018; 18: 82.

[5] Gera I, Gorzó I. Periodontitis as a risk factor of general systemic diseases - periodontal medicine. In Gera I. (ed.) Periodontology. [A fogágybetegség mint az általános szervezeti betegségek rizikófaktora - parodontalis medicina. In: Gera I. (szerk.) Parodontológia.] Semmelweis Kiadó, Budapest, 2009; pp. 203-217. [Hungarian]

[6] Macedo Paizan ML, Vilela-Martin JF. Is there an association between periodontitis and hypertension? Curr Cardiol Rev. 2014; 10: 355-361.

[7] Borbély J, Gera I, Fejérdy I, et al. Parodontal status of Hungarian adults: an epidemiologic study. [A hazai felnőtt lakosság parodontális állapota epidemiológiai felmérés alapján.] Fogorv Szle. 2011; 104: 39-47. [Hungarian]

[8] Nguyen CM, Kim JW, Quan VH, et al. Periodontal associations in cardiovascular diseases: the latest evidence and understanding. J Oral Biol Craniofac Res. 2015; 5: 203-206.

[9] Chistiakov DA, Orekhov AN, Bobryshev YV. Links between atherosclerotic and periodontal disease. Exp Mol Pathol. 2016; 100: 220-235.

[10] WHO. Summary tables of mortality estimates by cause, age and sex, globally and by region, 2000-2015 - Global summary estimates. Available from: http://www.who.int/healthinfo/global_ burden_disease/estimates/en/indexl.html [accessed: May 8, 2018]. 
[11] Mattila KJ, Nieminen MS, Valtonen VV, et al. Association between dental health and acute myocardial infarction. Br Med J. 1989; 298: 779-781.

[12] Mattila KJ, Valle MS, Nieminen MS, et al. Dental infections and coronary atherosclerosis. Atherosclerosis 1993; 103: 205-211.

[13] Emingil G, Buduneli E, Aliyev A, et al. Association between periodontal disease and acute myocardial infarction. J Periodontol. 2000; 71: 1882-1886.

[14] Geerts SO, Legrand V, Charpentier J, et al. Further evidence of the association between periodontal conditions and coronary artery disease. J Periodontol. 2004; 75: 1274-1280.

[15] Beck JD, Elter JR, Heiss G, et al. Relationship of periodontal disease to carotid artery intima-media wall thickness: the atherosclerosis risk in communities (ARIC) study. Arterioscler Thromb Vasc Biol. 2001; 21: 1816-1822.

[16] Shimazaki Y, Saito T, Kiyohara Y, et al. Relationship between electrocardiographic abnormalities and periodontal disease: the Hisayama Study. J Periodontol. 2004; 75: 791-797.

[17] Holmlund A, Holm G, Lind L. Severity of periodontal disease and number of remaining teeth are related to the prevalence of myocardial infarction and hypertension in a study based on 4,254 subjects. J Periodontol. 2006; 77: 1173-1178.

[18] Desvarieux M, Demmer RT, Jacobs DR Jr, et al. Periodontal bacteria and hypertension: the oral infections and vascular disease epidemiology study (INVEST). J Hypertens. 2010; 28: 1413-1421.

[19] DeStefano F, Anda RF, Kahn HS, et al. Dental disease and risk of coronary heart disease and mortality. BMJ 1993; 306: 688-691.

[20] Mendez MV, Scott T, LaMorte W, et al. An association between periodontal disease and peripheral vascular disease. Am J Surg. 1998; 176: 153-157.

[21] Hujoel PP, Drangsholt M, Spiekerman C, et al. Periodontal disease and coronary heart disease risk. JAMA 2000; 284: 14061410.

[22] Lafon A, Pereira B, Dufour T, et al. Periodontal disease and stroke: a meta-analysis of cohort studies. Eur J Neurol. 2014; 21 1155-1161.e66-e67.

[23] Rydén L, Buhlin K, Ekstrand E, et al. Periodontitis increases the risk of a first myocardial infarction: a report from the PAROKRANK Study. Circulation 2016; 133: 576-583.

[24] Beukers NG, van der Heijden GJ, van Wijk AJ, et al. Periodontitis is an independent risk indicator for atherosclerotic cardiovascular diseases among 60174 participants in a large dental school in the Netherlands. J Epidemiol Community Health 2017; 71 $37-42$.

[25] Bahekar AA, Singh S, Saha S, et al. The prevalence and incidence of coronary heart disease is significantly increased in periodontitis: a meta-analysis. Am Heart J. 2007; 154: 830-837.

[26] Blaizot A, Vergnes JN, Nuwwareh S, et al. Periodontal diseases and cardiovascular events: meta-analysis of observational studies. Int Dent J. 2009; 59: 197-209.

[27] Xu S, Song M, Xiong Y, et al. The association between periodon tal disease and the risk of myocardial infarction: a pooled analysis of observational studies. BMC Cardiovasc Disord. 2017; 17: 50

[28] Libby P, Ridker PM, Hansson GK. Inflammation in atherosclerosis: from pathophysiology to practice. J Am Coll Cardiol. 2009; 54: 2129-2138.

[29] László G, Matkó J, Prechl J, et al. The general structure of cell membrane and receptors, molecules on the surface of immune cells. In: Erdei A, Sármai G, Prechl J. (eds.) Immunology. [A sejtmembrán és a receptorok általános szerkezete, az immunsejtek sejtfelszíni molekulái. In: Erdei A, Sármai G, Prechl J. (szerk.) Immunológia.] Medicina Könyvkiadó, Budapest, 2012; pp. 99103. [Hungarian]

[30] Chiu B. Multiple infections in carotid atherosclerotic plaques. Am Heart J. 1999; 138(5 Pt 2): S534-S536.

[31] Haraszthy VI, Zambon JJ, Trevisan M, et al. Identification of periodontal pathogens in atheromatous plaques. J Periodontol. 2000 ; $71: 1554-1560$
[32] Zaremba M, Górska R, Suwalski P, et al. Periodontitis as a risk factor of coronary heart diseases? Adv Med Sci. 2006; 51(Suppl 1): 34-39.

[33] Loos BG. Systemic markers of inflammation in periodontitis. J Periodontol. 2005; 76(Suppl 11): 2106-2115.

[34] Schwahn C, Völzke H, Robinson DM, et al. Periodontal disease, but not edentulism, is independently associated with increased plasma fibrinogen levels. Results from a population-based study. Thromb Haemost. 2004; 92: 244-252.

[35] Bizzarro S, van der Velden U, ten Heggeler JM, et al. Periodontitis is characterized by elevated PAI-1 activity. J Clin Periodon tol. 2007 ; 34: 574-580.

[36] Tuomisto K, Jousilahti P, Sundvall J, et al. C-reactive protein, interleukin- 6 and tumor necrosis factor alpha as predictors of incident coronary and cardiovascular events and total mortality. A population-based, prospective study. Thromb Haemost. 2006; 95: $511-518$

[37] Passoja A, Puijola I, Knuuttila M, et al. Serum levels of interleukin-10 and tumour necrosis factor- $\alpha$ in chronic periodontitis. J Clin Periodontol. 2010; 37: 881-887.

[38] Ridker PM, Rifai N, Rose L, et al. Comparison of C-reactive protein and low-density lipoprotein cholesterol levels in the prediction of first cardiovascular events. N Engl J Med. 2002; 347: $1557-1565$.

[39] Paraskevas S, Huizinga JD, Loos BG. A systematic review and meta-analyses on C-reactive protein in relation to periodontitis. J Clin Periodontol. 2008; 35: 277-290.

[40] Nepomuceno R, Pigossi SC, Finoti LS, et al. Serum lipid levels in patients with periodontal disease: a meta-analysis and meta-regression. J Clin Periodontol. 2017; 44: 1192-1207.

[41] Amar S, Gokce N, Morgan S, et al. Periodontal disease is associated with brachial artery endothelial dysfunction and systemic inflammation. Arterioscler Thromb Vasc Biol. 2003; 23: 12451249.

[42] Higashi Y, Goto C, Jitsuiki D, et al. Periodontal infection is associated with endothelial dysfunction in healthy subjects and hypertensive patients. Hypertension 2008; 51: 446-453.

[43] Tsioufis C, Thomopoulos C, Soldatos N, et al. The conjoint detrimental effect of chronic periodontal disease and systemic in flammation on asymmetric dimethyl-arginine in untreated hypertensive subjects. Atherosclerosis 2010; 208: 258-263.

[44] Vidal F, Figueredo CM, Cordovil I, et al. Periodontal therapy reduces plasma levels of interleukin-6, C-reactive protein, and fibrinogen in patients with severe periodontitis and refractory arterial hypertension. J Periodontol. 2009; 80: 786-791.

[45] Freitas CO, Gomes-Filho IS, Naves RC, et al. Influence of periodontal therapy on C-reactive protein level: a systematic review and meta-analysis. J Appl Oral Sci. 2012; 20: 1-8.

[46] D'Aiuto F, Orlandi M, Gunsolley JC. Evidence that periodontal treatment improves biomarkers and CVD outcomes. J Clin Periodontol. 2013; 40(Suppl 14): S85-S105.

[47] Lockhart PB, Bolger AF, Papapanou PN, et al. Periodontal disease and atherosclerotic vascular disease: does the evidence support an independent association? A scientific statement from the American Heart Association. Circulation 2012; 125: 25202544.

[48] Tonetti MS, D'Aiuto F, Nibali L, et al. Treatment of periodontitis and endothelial function. N Engl J Med. 2007; 356: 911920.

[49] Saffi MAL, Rabelo-Silva ER, Polanczyk CA, et al. Periodontal therapy and endothelial function in coronary artery disease: a randomized controlled trial. Oral Dis. 2018; 24: 1349-1357.

[50] $\mathrm{Li} \mathrm{C}, \mathrm{Lv} \mathrm{Z}$, Shi Z, et al. Periodontal therapy for the management of cardiovascular disease in patients with chronic periodontitis. Cochrane Database Syst Rev. 2017; 11: CD009197.

(Gheorghita Dorottya dr.,

Szeged, Tisza Lajos körút 64-66., 6720 e-mail: ghdorottya@gmail.com)

A cikk a Creative Commons Attribution 4.0 International License (https://creativecommons.org/licenses/by/4.0/) feltételei szerint publikált Open Access közlemény. (SID_1) 